\title{
Assessment of Fatigue in Undifferentiated Spondyloarthritis (USpA)
}

\author{
Berat Meryem Alkan1, Fatma Fidan1, Sevgi Atalay', Şükran Erten1', Sinem Bozkurt1, \\ Özge Ardıçoğlu² \\ ${ }^{1}$ Ataturk Education and Research Hospital, PMR Clinic, Ankara, Turkey \\ ${ }^{2}$ Yildirim Beyazit University, PMR Clinic, Ankara, Turkey \\ Email: ${ }^{*}$ berat.alkan@ttmail.com
}

Received 22 May 2014; revised 22 June 2014; accepted 22 July 2014

Copyright (C) 2014 by authors and Scientific Research Publishing Inc.

This work is licensed under the Creative Commons Attribution International License (CC BY).

http://creativecommons.org/licenses/by/4.0/

(c) (i) 0 pen Access

\section{Abstract}

Objectives: This study aimed to evaluate the fatigue in patients with undifferentiated spondyloarthritis [USpA], and its relationship with disease-specific variables, spinal mobility measures and healthy related quality of life [HRQOL]. Methods: Eighty patients with USpA and forty healthy subjects were included in this study. The multidimensional assessment of fatigue [MAF] and the generic instrument Short Form 36 [SF 36] were used in patient and control groups to assess fatigue and [HRQOL]. Fatigue was also assessed with the Bath ankylosing spondylitis disease activity index [BASDAI] fatigue item. The evaluation included the activity of the disease [BASDAI], functional status [Bath ankylosing spondylitis functional index], and visual analog scale [VAS] of axial and joint pain. Demographics and disease-related data were obtained. Results: Patients with USpA had higher scores in MAF total and in all MAF subgroup scales than controls. All SF-36 subgroups scores were also found to be significantly lower in patients. Severe fatigue experienced $60 \%$ in patients. MAF total scores were found to be significantly correlated with morning stiffness, BASDAI, Bath ankylosing spondylitis functional index (BASFI), BASDAI fatigue, VAS-axial, and SF-36 subgroups scores in patients $[p<0.05]$. Conclusions: The patients with USpA defined significantly more fatigue and lower HRQOL when compared with healthy persons. MAF was found to be related with the clinical and functional status and health-related quality of life of patients with USpA.

\section{Keywords}

Undifferentiated Spondyloarthritis, MAF, HRQOL

\footnotetext{
${ }^{*}$ Corresponding author.
}

How to cite this paper: Alkan, B.M., Fidan, F., Atalay, S., Erten, Ş., Bozkurt, S. and Ardıçoğlu, Ö. (2014) Assessment of Fatigue in Undifferentiated Spondyloarthritis (USpA). Open Journal of Rheumatology and Autoimmune Diseases, 4, $153-161$. http://dx.doi.org/10.4236/ojra.2014.43022 


\section{Introduction}

Spondyloarthropathies [SpA] include a group of chronic inflammatory rheumatic conditions, which are characterized by inflammation of vertebrae, peripheral joints and periarticular tissues. Etiology is unknown but genetical tendency, infectious agents and environmental factors may play a role. Undifferentiated spondyloarthropathy [USpA] is a SpA subtype also characterized by inflammatory back pain and arthritis, and it does not conform to the criteria for Ankylosing spondylitis [AS], Reiter's syndrome, psoriatic arthritis or inflammatory bowel disease arthritis [1].

Bath ankylosing spondylitis functional index [BASFI] and disease activity index [BASDAI] are often used to evaluate the USpA condition [2]. A number of previous studies [3]-[5] indicating that BASDAI could reflect the disease activity of both USpA and AS patients. ASAS group has advised the fatigue question of the Bath Ankylosing Spondylitis Disease Activity Index [BASDAI] as the most appropriate measure of fatigue in daily practice [6].

The multidimensional assessment of fatigue scale [MAF] was appropriate to measure self-reported fatigue in adults with rheumatoid arthritis and other chronic conditions. The MAF is a self-administered questionnaire developed to measure five dimensions of self-reported fatigue: degree, severity, distress, impact on activities of daily living and timing [7].

To our knowledge, there is no study regarding the multidimensional nature of fatigue and health-related quality of life [HRQOL] in patients with USpA. This study aims to evaluate the fatigue in Turkish patients with USpA, and its relationships with disease-specific variables, spinal mobility measures and healthy-related quality of life [HRQOL].

\section{Materials and Methods}

Eighty patients who were admitted to our outpatient clinic and fulfilling European Spondyloarthropathy Study Group [ESSG] criteria for USpA [1]; and forty sedanter healthy volunteers were with similar demographic characteristics included in this study. All patients were over 18 years old [20 - 65 years]. Written consents were also obtained from each patient and healthy control. Patients with malignancies, fibromyalgia syndrome or other systemic inflammatory rheumatic diseases were not included in the study. Demographic variables were collected in all cases.

Assessment criteria in this study:

1. Duration of morning stiffness (minute), presence of night pain, history of peripheral arthritis, symptom duration (since the diagnosis of USpA), and metrological measures (finger-floor distance, lumbar schober, occiputwall distance, and chest expansion) were measured.

2. Visual analog scale [VAS] was used to determine the pain intensity related to USpA [0 - 10], $0=$ no pain and $10=$ severe pain imaginable.

3. The Bath Ankylosing Spondylitis Disease Activity Index translated into Turkish dialect and validated was used to assess self-reported disease activity [8]. Three levels of disease activity were defined: a score $<4$ meant mildly active disease, a score of 4 - 6 indicated moderate disease activity, and a score of $>6$ defined severe disease activity [9]. The question related to fatigue in the BASDAI was evaluated separately. Patients who have BASDAI score of $>5$ are accepted to have fatigue.

4. The Bath ankylosing spondylitis functional index [BASFI] was used to assess the functional status. It comprises ten VAS questions measuring the functional ability in the previous week. Scores on each item range from 0 [easy] to 10 [impossible]. The final score is calculated by a mean of the ten items, higher scores indicating more disability [10] [11].

5. Erythrocyte sedimentation rate [ESR] and serum C-reactive protein [CRP] were determined and applied as biologic signs of inflammation. Human leukocyte antigen b27 [HLA B27] status was determined with available records.

6. The generic instrument Short Form 36 [SF 36] was used to assess health related quality of life. The SF-36 is a widely applied instrument for measuring health status and consists of eight dimensions: physical functioning, social functioning, physical role, emotional role, mental health, vitality, bodily pain and general health perceptions. Scores range from 0 [worst] to 100 [best] with higher scores indicating better health status [12] [13]. SF36 was also used to assess fatigue in control group.

7. Fatigue was evaluated using the first item of the BASDAI questionnaire "how could you describe the over- 
all level of fatigue/tiredness you have?” The answer was recorded using a 0 - 10 VAS scale $[0=$ no fatigue and $10=$ worst fatigue imaginable]. Patients who have BASDAI score of $>5$ are accepted to have fatigue. The MAF was also used to assess fatigue. It was originally developed to measure self-reported fatigue in adults with rheumatoid arthritis, but subsequently has been used to measure fatigue in other chronic conditions. The MAF is a self-administered questionnaire developed to measure five dimensions of self-reported fatigue: degree [MAF1], severity [MAF2], distress [MAF3], impact on activities of daily living [MAF4] and timing [MAF5]. It contains 16 items. The MAF score ranged from 0 [no fatigue] to 50 [severe fatigue] [7]. MAF was also used to assess fatigue in control group.

Patients were dichotomized into a Fatigue + group if the BASDAI fatigue score was $>5$ and a Fatigue - group if the fatigue score was $\leq 5$.

\section{Statistics}

Data were analyzed using SPSS version 17.0 for Windows. Descriptive statistics were used to describe demographic characteristics. Comparative analyses of demographic characteristics between patients and controls were computed using either the Man-Whitney U test or the Chi squared test depending on the levels of measurement. Mean group scores were compared using Man-Whitney U test between patients and controls and BASDAI fatigue groups. Spearman correlation tests were used to determine the relationships between the variables. The level of significance was set at $\mathrm{p}<0.05$.

\section{Results}

Eighty patients with USpA [68 females, 12 males] and forty healthy controls [30 females, 10 males] were included in the study. The ages of the USpA patients were between 20 and 65 years [mean $47.22 \pm 10.31$ ]. The ages of healthy controls were between 23 and 70 years [mean $43.12 \pm 8.11$ ]. There was no statistically significant difference in gender, body mass index [BMI], and ages of patients with USpA and controls [p $>0.05]$. The mean total score of MAF was $29.97 \pm 12.11$ in patients. Patients with USpA had significantly higher scores in MAF total and all MAF subgroup scales than controls. All SF-36 subgroups scores were also found to be significantly lower in patients. [p $<0.000$ ] (Table 1). The demographical and clinical data were shown in Table 2.

It was observed that $60 \%$ of USpA patients had fatigue [BASDAI fatigue $>5$ ]. Sixty percent [48] of the patients were included in the Fatigue + group, and forty percent [32] of the patients were in the Fatigue - group. atigue + group scored significantly different from the Fatigue - group with respect to each subscales of the MAF, all disease-specific variables [duration of morning stiffness, history of night pain, chest expansion, BASDAI, and BASFI], and VAS-axial, VAS-peripheral and all the SF-36 subgroups scores except role emotional [RE] and role physical of SF 36. In Fatigue - group, presence of HLA B27 was significantly higher than Fatigue + group [p $>0.05]$ (Table 3).

Clinical and demographic data and disability scores in patients with USpA and correlations with MAF scores were summarized in Table 4. In patients, the MAF total score was found to be significantly correlated with duration of morning stiffness, BASDAI, BASFI, BASDAI fatigue, and VAS-axial $[\mathrm{p}<0.05$ and $\mathrm{r}<-0.5$ or $\mathrm{p}<$ 0.05 and $r>0.5$ ]. No correlation was observed between MAF total score and age, BMI, education level, disease duration, metrological measures, ESR, CRP, and medications in patients.

Correlations between dimensions of MAF and dimensions of SF-36 in patients with USpA were shown in Table 5. In patients group, MAF total score were found to be significantly correlated with the all SF-36 subgroups scores except RE and MH subgroups scores of SF-36 [p $<0.05$ and $r<-0.5$ or $\mathrm{p}<0.05$ and $\mathrm{r}>0.5$ ].

\section{Discussion}

The results of our study, which assessed fatigue multidimensionally by MAF revealed that patients with USpA had significantly higher fatigue scores when compared with healthy controls. In this study, HRQOL was evaluated by SF-36 in patients diagnosed with USpA and healthy controls. According to the results of the current study, there was a statistically significant impairment in the all subscales of the quality of life in patients. To our knowledge, this is the first study which compares fatigue and HRQOL in patients with USpA and healthy persons.

Only a few studies have been published examining determinants of fatigue in $\mathrm{SpA}$, and all have focused on ankylosing spondylitis [AS] [14]. To our knowledge, there is no study which have been published examining 
Table 1. Comparison of mean scores of SF-36 subgroups, and demographic data in patients with undifferentiated spondyloarthritis and healthy controls, ${ }^{*} \mathrm{P}<0.001$.

\begin{tabular}{|c|c|c|c|}
\hline & $\begin{array}{c}\text { Patients }(\mathrm{n}=80) \\
(\text { mean } \pm \text { SD) }(\text { min-max })\end{array}$ & $\begin{array}{l}\text { Control (n = 40) P value } \\
\text { (mean } \pm \text { SD) (min-max) }\end{array}$ & $P$ value \\
\hline Age (years) & $47.22 \pm 10.31(20-65)$ & $43.12 \pm 8.11(23-70)$ & 0.105 \\
\hline Males/Females \% (n) & 15\%/85\% (12 - 68) & $\%$ 25/\%75 (30 - 10) & 0.182 \\
\hline Body mass index $\left(\mathrm{kg} / \mathrm{m}^{2}\right)$ & $32.73 \pm 5(22-45)$ & $31.18 \pm 4.4(26-42)$ & 0.058 \\
\hline \multicolumn{4}{|l|}{ SF-36 subgroups } \\
\hline Physical function (PF) & $60.17 \pm 21.3(24-100)$ & $79.12 \pm 10.8(50-100)$ & $0.000^{*}$ \\
\hline Role physical (RP) & $45.31 \pm 41.1(0-100)$ & $80 \pm 29.5(0-100)$ & $0.000^{*}$ \\
\hline Bodily pain(BP) & $41.38 \pm 17.4(10-84)$ & $67.90 \pm 17.8(10-100)$ & $0.000^{*}$ \\
\hline General health (GH) & $42.21 \pm 17.7(0-87)$ & $57.47 \pm 13.9(5-82)$ & $0.000^{*}$ \\
\hline Vitality (VT) & $32.83 \pm 23.3(0-85)$ & $49.25 \pm 16.9(0-75)$ & $0.000^{*}$ \\
\hline Social function (SF) & $55.60 \pm 25.9(0-100)$ & $80.62 \pm 19.6(0-100)$ & $0.000^{*}$ \\
\hline Role emotional (RE) & $40.39 \pm 40.6(0-100)$ & $77.16 \pm 32.9(0-100)$ & $0.000^{*}$ \\
\hline Mental health (MH) & $42.85 \pm 18.12(0-88)$ & $63.27 \pm 18.3(36-100)$ & $0.000^{*}$ \\
\hline PCS & $39.49 \pm 9.3(23.2-58.80)$ & $65.95 \pm 13.2(34.4-86)$ & $0.000^{*}$ \\
\hline MCS & $34.78 \pm 10.3(9.2-58.50)$ & $64.98 \pm 12.7(40-88.4)$ & $0.000^{*}$ \\
\hline \multicolumn{4}{|c|}{ MAF subgroups (mean) (min-max) } \\
\hline MAF-1 (degree) & $6.26 \pm 2.51(0-10)$ & $4.42 \pm 2.26(0-9)$ & $0.000^{*}$ \\
\hline MAF-2 (severity) & $6.08 \pm 2.61(0-10)$ & $4.12 \pm 2.55(0-9)$ & $0.000^{*}$ \\
\hline MAF-3 (distress) & $5.98 \pm 2.64(0-9)$ & $3.82 \pm 2.30(0-8)$ & $0.000^{*}$ \\
\hline MAF-4 (ADLs) & $5.35 \pm 2.39(0-8.81)$ & $3.53 \pm 2.0(0-7)$ & $0.000^{*}$ \\
\hline MAF-5 (timing) & $6.23 \pm 2.66(0-10)$ & $4.26 \pm 2.53(0-10)$ & $0.000^{*}$ \\
\hline MAF total & $29.97 \pm 12.11(0-47.47)$ & $19.92 \pm 11.01(0-38)$ & $0.000^{*}$ \\
\hline
\end{tabular}

SF-36: Short Form 36, PCS: Physical component summary, MCS: Mental component summary, MAF: Multidimensional assessment of fatigue, ADLs: Impact on activities of daily living.

determinants of fatigue in USpA. We assessed the properties of both the single-item question and a multidimensional assessment of fatigue questionnaire, the MAF in patients with USpA. The advantage of a single item BASDAI fatigue question is that it is very easy to complete. ASAS group has also adviced the fatigue question of the BASDAI as the most appropriate measure of fatigue in daily practice [6]. Advantage of the MAF is that it gives more details about different aspects of fatigue [14].

In our research, $60 \%$ of all patients experienced fatigue, determined as a BASDAI fatigue score of $>5$. Our findings suggest that fatigue is an important symptom in USpA. The other study reported that Fifty-nine percent of patients with SpA moderate to high levels of fatigue [15]. In this study, fatigue levels of the patients were found to be related to disease-specific variables [duration of morning stiffness, history of night pain, chest expansion, BASDAI, BASFI], level of axial and peripheral joint pain, the MAF and HRQOL. In present study, the MAF total score was also found to be significantly correlated with duration of morning stiffness, BASDAI, BASFI, BASDAI fatigue, and axial pain in patients. [p < 0.05]. In patients with SpA, similar relationships between fatigue and measures of self-reported disease activity, limitations in functional abilities, stiffness, and pain have also been reported by other studies [6] [16]-[18].

Different generic and disease specific instruments are available in measuring HRQOL. In this study we used the SF-36 questionnaire that is one of the most frequently used generic tools for musculoskeletal disorders and 
Table 2. Demographic and clinical data in patients with undifferentiated spondyloarthritis.

\begin{tabular}{|c|c|c|}
\hline \multicolumn{3}{|c|}{$\mathrm{N}=80$} \\
\hline \multicolumn{2}{|c|}{ Symptom duration (years) mean \pm SD (min-max) } & $8.93 \pm 7.16(1-20)$ \\
\hline \multicolumn{2}{|c|}{ Morning stiffness (min) mean \pm SD (min-max) } & $43 \pm 41.02(0-180)$ \\
\hline \multicolumn{2}{|c|}{ History of night pain \% (n) } & $62.5 \%(50)$ \\
\hline \multicolumn{2}{|c|}{ History of peripheral arthritis \% (n) } & $85 \%(68)$ \\
\hline \multicolumn{2}{|c|}{ Presence of HLAB 27\% (n) } & $37.5 \%(30)$ \\
\hline \multirow{4}{*}{$\begin{array}{l}\text { Metrological measures } \\
\text { mean } \pm \text { SD (min-max) }\end{array}$} & Finger floor distance & $15.43 \pm 9.11(0-43)$ \\
\hline & Dorsal Schober's & $5 \pm 1.08(3-8)$ \\
\hline & Occiput-wall distance & $7.15 \pm 2.16(2-14)$ \\
\hline & Chest expansion & $3.98 \pm 1.11(2-8)$ \\
\hline \multicolumn{2}{|c|}{ VAS axial mean \pm SD (min-max) } & $6.81 \pm 2.38(0-10)$ \\
\hline \multicolumn{2}{|c|}{ VAS peripheral mean \pm SD (min-max) } & $5.82 \pm 2.92(0-10)$ \\
\hline \multicolumn{2}{|c|}{ BASDAI mean \pm SD (min-max) } & $5.59 \pm 2.05(0-10)$ \\
\hline \multicolumn{2}{|c|}{ BASDAI fatigue $>5 \%(n)$} & $60 \%(48)$ \\
\hline \multicolumn{2}{|c|}{ BASFI mean \pm SD (min-max) } & $4.89 \pm 1.90(0-10)$ \\
\hline & No therapy \%(n) & $12.5 \%(10)$ \\
\hline \multirow[t]{2}{*}{ Medications } & NSAID \%(n) & $13.8 \%(11)$ \\
\hline & DMARD + NSAID \%(n) & $73.8 \%(59)$ \\
\hline \multicolumn{2}{|c|}{ Sedim $(\mathrm{mm} / \mathrm{h})$} & $18.69 \pm 14.55(4-85)$ \\
\hline \multicolumn{2}{|c|}{ CRP (mg/dl) } & $1.53 \pm 1.39(0.1-6.7)$ \\
\hline
\end{tabular}

ESR: Erythrocyte sedimentation rate, CRP: C reactive protein, BASDAI: Bath ankylosing spondylitis disease activity index, BASFI: Bath ankylosing spondyliti functional index, NSAID: Non-steroidal anti-inflammatory drugs, DMARD: Disease modifying antirheumatic drugs, HLA-B27: Human leukocyte antigen b27.

other chronic conditions. We found that fatigue was significantly correlated with all SF-36 dimensions except RE and MH of SF 36, physical component summary [PCS] and mental component summary [MCS]. In studies investigating fatigue and health-related quality of life, an association was reported between fatigue and mental health [6] [19]. We also found a statistically significant correlation between mental component summary and fatigue. It can be thought that the association between fatigue and worse mental health may in part be explained by depression.

A recent study [20] showed that nonsteroidal antiinflammatory drug therapy strongly reduced pain and functional impairment in a group of AS patients, whereas the change in fatigue level was of lower magnitude. Similarly in other studies, we found no impact of nonsteroidal anti-inflammatory drugs [NSAID] and disease-modifying antirheumatic drugs [DMARD] on fatigue degree [14] [21]. In our study, laboratory measurements like ESR and CRP were no found to be related with fatigue. Both CRP and ESR are nonspecific markers of inflammation that correlate with disease activity. Similarly recent studies [22] [23] showed no relationship between fatigue and inflammatory markers [ESR, CRP]. Thus, the relationship between fatigue and inflammatory markers is unclear, and more studies are needed to explore the issue [19].

USpA are frequently characterized by isolated episodes of peripheral arthritis and enthesitis, axial or back pain and by a lower incidence of HLA-B27 versus AS [24]. In our present study, incidence of HLA-B27 was 37.5\% in patients with USpA. In our Fatigue - group, presence of HLAB27 was significantly higher than Fatigue + group [p > 0.05]. The relationship between fatigue and presence of HLAB27 is unclear, and more studies are needed in USpA patients. 
Table 3. Differences between Fatigue + group and Fatigue - group with respect to demographic and clinical data, the disease-specific measures, subscales of MAF and SF-36 in patients with undifferentiated spondyloarthritis. ( ${ }^{*} \mathrm{P}$ $\left.<0.05,{ }^{* *} \mathrm{P}<0.005\right)$.

\begin{tabular}{|c|c|c|c|}
\hline mean \pm SD) (min-max) & $\begin{array}{c}\text { BASDAI fatigue } \leq 5 \\
N=32(40 \%)\end{array}$ & $\begin{array}{c}\text { BASDAI fatigue }>5 \\
N=48(60 \%)\end{array}$ & $\begin{array}{c}\mathrm{P} \\
\text { values }\end{array}$ \\
\hline Age (years) & $46.05 \pm 12.3(20-65)$ & $48 \pm 8.7(27-65)$ & 0.783 \\
\hline Body mass index $\left(\mathrm{kg} / \mathrm{m}^{2}\right)$ & $32.01 \pm 5.03(22-44)$ & $33.21 \pm 4.77(23-45)$ & 0.176 \\
\hline Female \% (n) & $75 \%(24)$ & $91.7 \%(44)$ & 0.056 \\
\hline Disease duration & $8.08 \pm 7.09(1-20)$ & $9.37 \pm 7.25(2-20)$ & 0.403 \\
\hline Duration morning stiffness (min) & $27.50 \pm 32.7(0-120)$ & $53.33 \pm 43(0-180)$ & $0.002^{* *}$ \\
\hline History of night pain \% (n) & $46.9 \%(15)$ & $72.9 \%(35)$ & $0.018^{*}$ \\
\hline History of peripheral arthritis \% (n) & $78.1 \%(25)$ & $89.6 \%(43)$ & 0.206 \\
\hline Presence of HLAB27\% (n) & $56.25 \%(18)$ & $43.75 \%(12)$ & $0.022^{*}$ \\
\hline \multicolumn{4}{|l|}{ Metrological measures } \\
\hline Finger-floor distance & $13.09 \pm 7.14(0-30)$ & $16.93 \pm 9.73(0-43)$ & 0.08 \\
\hline Dorsal Schober's & $5.32 \pm 1.26(3-8)$ & $4.79 \pm 0.89(3-8)$ & 0.101 \\
\hline Occiput-wall distance & $6.89 \pm 2.24(2-14)$ & $7.32 \pm 2.12(2-12)$ & 0.516 \\
\hline Chest expansion & $4.37 \pm 1.23(2-8)$ & $3.72 \pm 0.94(2-6)$ & $0.014^{*}$ \\
\hline VAS axial & $5.71 \pm 2.58(0-10)$ & $7.53 \pm 1.96(0-10)$ & $0.001^{* *}$ \\
\hline VAS peripheral & $4.97 \pm 3.18(0-10)$ & $6.38 \pm 2.60(0-10)$ & $0.043^{*}$ \\
\hline BASDAI & $4.25 \pm 1.83(1-7.6)$ & $6.49 \pm 1.65(2.18-9.8)$ & $0.000^{* *}$ \\
\hline BASFI & $4.0 \pm 1.99(0-7.90)$ & $5.48 \pm 1.611(2.55-8.7)$ & $0.001^{* *}$ \\
\hline \multicolumn{4}{|l|}{ SF-36 subgroups } \\
\hline Physical function (PF) & $70.28 \pm 21.09(24-100)$ & $53.43 \pm 18.53(25-100)$ & $0.001^{* *}$ \\
\hline Role physical (RP) & $56.25 \pm 44.45(0-100)$ & $38.02 \pm 37.54(0-100)$ & 0.088 \\
\hline Bodily pain (BP) & $49.78 \pm 16.06(22-84)$ & $35.79 \pm 16.17(16-84)$ & $0.000^{* *}$ \\
\hline General health (GH) & $53.53 \pm 16.06(20-87)$ & $34.66 \pm 14.52(0-72)$ & $0.000^{* *}$ \\
\hline Vitality (VT) & $46.56 \pm 20.96(4-80)$ & $23.68 \pm 20.33(0-85)$ & $0.000^{* *}$ \\
\hline Social function (SF) & $69.50 \pm 20.81(25-100)$ & $46.34 \pm 24.98(0-100)$ & $0.000^{* *}$ \\
\hline Role emotional (RE) & $53.06 \pm 45.49(0-100)$ & $31.95 \pm 35.02(0-100)$ & 0.087 \\
\hline Mental health (MH) & $49.25 \pm 18.41(0-88)$ & $38.58 \pm 16.79(12-88)$ & $0.003^{* *}$ \\
\hline Physical component summary (FCS) & $43.59 \pm 8.96(25-58.80)$ & $36.75 \pm 8.73(23.2-56.3)$ & $0.001^{* *}$ \\
\hline Mental component summary (MCS) & $39.74 \pm 10.46(9.2-58.5)$ & $31.48 \pm 8.89(17.3-58.4)$ & $0.000^{* *}$ \\
\hline \multicolumn{4}{|l|}{ MAF subgroups } \\
\hline MAF-1 (degree) & $4.43 \pm 2.81(0-9)$ & $7.47 \pm 1.28(4-10)$ & $0.000^{* *}$ \\
\hline MAF-2 (severity) & $4.15 \pm 2.93(0-8)$ & $7.37 \pm 1.28(5-10)$ & $0.000^{* *}$ \\
\hline MAF-3 (distress & $3.96 \pm 2.97(0-8)$ & $7.33 \pm 1.11(5-9)$ & $0.000^{* *}$ \\
\hline MAF-4 (ADLs) & $3.77 \pm 2.58(0-7.81)$ & $6.40 \pm 1.55(2.27-8.81)$ & $0.000^{* *}$ \\
\hline MAF-5 (timing) & $4.77 \pm 3.16(0-10)$ & $7.19 \pm 1.69(2.5-10)$ & $0.001^{* *}$ \\
\hline MAF total & $21.05 \pm 13.87(0-40.65)$ & $35.92 \pm 5.42(25-47.47)$ & $0.000^{* *}$ \\
\hline
\end{tabular}

MAF: Multidimensional assessment of fatigue, ADLs: Impact on activities of daily living, BASDAI: Bath ankylosing spondylitis disease activity index, BASFI: Bath ankylosing spondylitis functional index. 
Table 4. Correlation between MAF subgroups, disability scores, clinical variables, and demographic characteristics in patients with undifferentiated spondyloarthritis. ( ${ }^{*} \mathrm{P}<0.05$ and $\mathrm{r}<-0.5$ or $\mathrm{P}<0.05$ and $\mathrm{r}>0.5$ ).

\begin{tabular}{|c|c|c|c|c|c|c|}
\hline & MAF-1 & MAF-2 & MAF-3 & MAF-4 & MAF-5 & MAF TOTAL \\
\hline r values & -0.021 & -0.050 & 0.034 & 0.202 & 0.044 & 0.020 \\
\hline $\mathrm{P}$ values & 0.853 & 0.661 & 0.766 & 0.073 & 0.702 & 0.863 \\
\hline \multirow[t]{2}{*}{ BMI } & 0.020 & 0.037 & 0.007 & 0.090 & 0.148 & 0.094 \\
\hline & 0.858 & 0.745 & 0.950 & 0.429 & 0.190 & 0.408 \\
\hline \multirow[t]{2}{*}{ Education level } & -0.231 & -0.217 & -0.256 & -0.240 & -0.166 & -0.267 \\
\hline & 0.039 & 0.054 & 0.022 & 0.032 & 0.140 & 0.017 \\
\hline \multirow[t]{2}{*}{ Duration morning stiffness } & 0.496 & 0.520 & 0.521 & 0.408 & 0.456 & 0.574 \\
\hline & 0.000 & $0.000^{*}$ & $0.000^{*}$ & 0.000 & 0.000 & $0.000^{*}$ \\
\hline \multirow[t]{2}{*}{ Disease duration } & 0.183 & 0.201 & 0.261 & 0.361 & 0.173 & 0.247 \\
\hline & 0.105 & 0.073 & 0.019 & 0.001 & 0.125 & 0.027 \\
\hline \multirow[t]{2}{*}{ Finger-floor distance } & 0.224 & 0.208 & 0.203 & 0.241 & 0.169 & 0.219 \\
\hline & 0.047 & 0.066 & 0.073 & 0.032 & 0.137 & 0.056 \\
\hline \multirow[t]{2}{*}{ Dorsal Schober’s } & 0.042 & 0.072 & 0.113 & 0.147 & 0.066 & 0.095 \\
\hline & 0.710 & 0.525 & 0.330 & 0.193 & 0.562 & 0.402 \\
\hline \multirow[t]{2}{*}{ Occiput-wall distance } & 0.055 & 0.044 & 0.044 & 0.1788 & 0.101 & 0.031 \\
\hline & 0.629 & 0.696 & 0.700 & 0.114 & 0.371 & 0.785 \\
\hline \multirow[t]{2}{*}{ Chest expansion } & -0.258 & -0.295 & -0.225 & -0.303 & -0.076 & -0.247 \\
\hline & 0.021 & 0.008 & 0.044 & 0.006 & 0.501 & 0.027 \\
\hline \multirow[t]{2}{*}{ BASDAI } & 0.640 & 0.601 & 0.655 & 0.521 & 0.647 & 0.647 \\
\hline & $0.000^{*}$ & $0.000^{*}$ & $0.000^{*}$ & $0.000^{*}$ & $0.000^{*}$ & $0.000^{*}$ \\
\hline \multirow[t]{2}{*}{ BASFI } & 0.523 & 0.589 & 0.632 & 0.595 & 0.607 & 0.667 \\
\hline & $0.000^{*}$ & $0.000^{*}$ & $0.000^{*}$ & $0.000^{*}$ & $0.000^{*}$ & $0.000^{*}$ \\
\hline \multirow[t]{2}{*}{ BASDAI fatigue } & 0.595 & 0.608 & 0.628 & 0.541 & 0.448 & 0.605 \\
\hline & $0.000^{*}$ & $0.000^{*}$ & $0.000^{*}$ & $0.000^{*}$ & 0.000 & $0.000^{*}$ \\
\hline \multirow[t]{2}{*}{ VAS-axial } & 0.583 & 0.529 & 0.585 & 0.507 & 0.569 & 0.622 \\
\hline & $0.000^{*}$ & $0.000^{*}$ & $0.000^{*}$ & $0.000^{*}$ & $0.000^{*}$ & $0.000^{*}$ \\
\hline \multirow[t]{2}{*}{ VAS-peripheral } & 0.358 & 0.228 & 0.291 & 0.445 & 0.473 & 0.391 \\
\hline & 0.001 & 0.043 & 0.009 & 0.000 & 0.000 & 0.000 \\
\hline \multirow[t]{2}{*}{ ESR } & 0.113 & 0.071 & 0.109 & 0.002 & 0.043 & 0.107 \\
\hline & 0418 & 0.612 & 0.412 & 0.988 & 0.755 & 0.441 \\
\hline \multirow[t]{2}{*}{ CRP } & -0.121 & -0.193 & -0.243 & -0.202 & -0.222 & -0.223 \\
\hline & 0.382 & 0.161 & 0.076 & 0.143 & 0.107 & 0.105 \\
\hline \multirow[t]{2}{*}{ Medications } & -0.099 & -0.140 & -0.160 & -0.034 & -0.025 & -0.146 \\
\hline & 0.382 & 0.215 & 0.157 & 0.762 & 0.250 & 0.196 \\
\hline
\end{tabular}

MAF: Multidimensional assessment of fatigue, BASDAI: Bath ankylosing spondylitis disease activity index, BASFI: Bath ankylosing spondylitis functional index, ESR: Erythrocyte sedimentation rate, CRP: C reactive protein, BMI: Body mass index. 
Table 5. Correlation between dimensions of SF-36 and dimensions of MAF Short Form 36 in patients with undifferentiated spondyloarthritis. ( ${ }^{*} \mathrm{P}<0.05$ and $\mathrm{r}<-0.5$ or $\mathrm{P}<0.05$ and $\mathrm{r}>0.5$ ).

\begin{tabular}{|c|c|c|c|c|c|c|}
\hline & MAF-1 & MAF-2 & MAF-3 & MAF-4 & MAF-5 & MAF TOTAL \\
\hline \multirow[t]{2}{*}{ Physical function (PF) } & -0.502 & -0.527 & -0.566 & -0.381 & -0.602 & -0.582 \\
\hline & $0.000^{*}$ & $0.000^{*}$ & $0.000^{*}$ & 0.000 & $0.000^{*}$ & $0.000^{*}$ \\
\hline \multirow[t]{2}{*}{ Role physical (RP) } & -0.503 & -0.428 & -0.501 & -0.311 & -0.502 & -0.510 \\
\hline & $0.000^{*}$ & 0.000 & $0.000^{*}$ & 0.000 & $0.000^{*}$ & $0.000^{*}$ \\
\hline \multirow[t]{2}{*}{ Bodily pain (BP) } & -0.615 & -0.613 & -0.664 & -0.512 & -0.637 & -0.688 \\
\hline & $0.000^{*}$ & $0.000^{*}$ & $0.000^{*}$ & $0.000^{*}$ & $0.000^{*}$ & $0.000^{*}$ \\
\hline \multirow[t]{2}{*}{ General health (GH) } & -0.571 & -0.674 & -0.676 & -0.530 & -0.572 & -0.700 \\
\hline & $0.000^{*}$ & $0.000^{*}$ & $0.000^{*}$ & $0.000^{*}$ & $0.000^{*}$ & $0.000^{*}$ \\
\hline \multirow[t]{2}{*}{ Vitality (VT) } & -0.570 & -0.650 & -0.617 & -0.561 & -0.429 & -0.644 \\
\hline & $0.000^{*}$ & $0.000^{*}$ & $0.000^{*}$ & $0.000^{*}$ & 0.000 & $0.000^{*}$ \\
\hline \multirow[t]{2}{*}{ Social function (SF) } & -0.633 & -0.622 & -0.687 & -0.671 & -0.522 & -0.726 \\
\hline & $0.000^{*}$ & $0.000^{*}$ & $0.000^{*}$ & $0.000^{*}$ & $0.000^{*}$ & $0.000^{*}$ \\
\hline \multirow[t]{2}{*}{ Role emotional (RE) } & -0.370 & -0.360 & -0.364 & -0.115 & -0.277 & -0.335 \\
\hline & 0.001 & 0.001 & 0.001 & 0.308 & 0.013 & 0.002 \\
\hline \multirow[t]{2}{*}{ Mental health (MH) } & -0.354 & -0.409 & -0.425 & -0.366 & -0.197 & -0.396 \\
\hline & 0.001 & 0.000 & 0.000 & 0.001 & 0.079 & 0.000 \\
\hline \multirow[t]{2}{*}{ PCS } & -0.542 & -0.530 & -0.581 & -0.439 & -0.657 & -0.625 \\
\hline & $0.000^{*}$ & $0.000^{*}$ & $0.000^{*}$ & 0.000 & $0.000^{*}$ & $0.000^{*}$ \\
\hline \multirow[t]{2}{*}{ MCS } & -0.509 & -0.549 & -0.557 & -0.472 & -0.296 & -0.542 \\
\hline & $0.000^{*}$ & $0.000^{*}$ & $0.000^{*}$ & 0.000 & 0.008 & $0.000^{*}$ \\
\hline
\end{tabular}

PCS: Physical component summary of SF 36, MCS: Mental component summary of SF 36.

Finally, major limitations of our study are the cross-sectional feature and relatively small number of subjects included in the study. Further prospective longitudinal studies are needed to establish the definitive relationship between spinal mobility, quality of life, and fatigue in USpA patients.

\section{Conclusion}

In conclusion, the patients with USpA defined significantly more fatigue and lower HRQOL when compared with healthy persons. It was found that the disease activity, limitations in functional abilities, stiffness, pain and HRQOL were significantly correlated with fatigue in patients with USpA. Similarly to other SpA, fatigue, as a major symptom of USpA, should be measured with respect to its intensity with appropriate measures, such as MAF. MAF provided more insight into specific dimensions of fatigue. Since MAF is short and easy to complete, it can be used in clinical practice.

\section{Conflict of Interest}

No conflict of interest is declared by authors.

\section{References}

[1] Dougados, M., Linden, S., Juhlin, R., et al. (1991) The European Spondyloarthropathy Study Group Preliminary Criteria for the Classification Spondyloarthropathy. Arthritis \& Rheumatism, 34, 1218-1227. http://dx.doi.org/10.1002/art.1780341003

[2] Lin, Z., Gu, J., He, P., et al. (2011) Multicenter Validation of the Value of BASFI and BASDAI in Chinese Ankylosing 
Spondylitis and Undifferentiated Spondyloarthropathy Patients. Rheumatology International, 3, 233-238. http://dx.doi.org/10.1007/s00296-009-1313-9

[3] Spoorenberg, A., Heijde, D., Klerk, E., et al. (1999) A Comparative Study of the Usefulness of the Bath Ankylosing spondylitis Functional Index and the Dougados Functional Index in the Assessment of Ankylosing Spondylitis. The Journal of Rheumatology, 26, 961-965.

[4] Claudepierre, P., Sibila, J., Goupille, P., et al. (1997) Evaluation of a French Version of the Bath Ankylosing spondylitis Disease Activity İndex in Patients with Spondylarthropathy. Journal of Rheumatology, 24, 1954-1958.

[5] Keikkila, S., Vitanen, J.V., Kautiainen, H., et al. (2002) Functional Long Term Changes in Patients with Spondyloarthropathy. Clinical Rheumatology, 21, 119-122. http://dx.doi.org/10.1007/s10067-002-8270-y

[6] Van Tubergen, A., Coenen, J., Landewé, R., et al. (2002) Assessment of Fatigue in Patients with Ankylosing Spondylitis: Apsychometric Analysis. Arthritis Care \& Research, 47, 8-16. http://dx.doi.org/10.1002/art1.10179

[7] Neuberger, G.B. (2003) Measures of Fatigue. Arthritis Care \& Research, 49, 175-183. http://dx.doi.org/10.1002/art.11405

[8] Akkoc, Y., Karatepe, A.G., Akar, S., et al. (2005) A Turkish Version of the Bath Ankylosing Spondylitis Disease Activity index: Reliability and Validity. Rheumatology International, 25, 280-284. http://dx.doi.org/10.1007/s00296-003-0432-y

[9] Garrett, S.L., Jenkinson, T.R., Kennedy, L.G., et al. (1994) A New Approach to Defining Disease Status in Ankylosing spondylitis: The Bath Ankylosing Spondylitis Disease Activity İndex. The Journal of Rheumatology, 21, $2286-2291$.

[10] Calin, A., Garrett, S.L., Whitelock, H.C., et al. (1994) A New Approach to Defining Functional Ability in Ankylosing Spondylitis: The Development of the Bath Ankylosing Spondylitis Functional Index (BASFI). The Journal of Rheumatology, 21, 2281-2285.

[11] Yanik, B., Gursel, Y.K., Kutlay, S., et al. (2005) Adaptation of the Bath Ankylosing Spondylitis Functional İndex to the Turkish Population, Its Reliability and Validity: Functional Assessment in AS. Clinical Rheumatology, 24, 41-47. http://dx.doi.org/10.1007/s10067-004-0968-6

[12] Ware Jr., J.E. (2000) SF-36 Health Survey Update. Spine, 25, 3130-3139. http://dx.doi.org/10.1097/00007632-200012150-00008

[13] Koçyiğit, H., Aydemir, Ö., Fişek, G., et al. (1999) Kısa Form 36'nın Türkçe Versiyonunun Güvenilirliği ve Geçerliliği. Ilaç ve Tedavi Dergisi, 12, 102-106.

[14] Aissaoui, N., Rostom, S., Hakkou, J., et al. (2012) Fatigue in Patients with Ankylosing Spondylitis: Prevalence and Relationships with Disease-Specific Variables, Psychological Status, and sleep Disturbance. Rheumatology International, 32, 2117-2124. http://dx.doi.org/10.1007/s00296-011-1928-5

[15] Da Costa, D., Dritsa, M., Ring, A., et al. (2004) Mental Health Status and Leisure-Time Physical Activity Contribute to Fatigue Intensity in Patients With Spondylarthropathy. Arthritis \& Rheumatism (Arthritis Care \& Research), 51, 10041008. http://dx.doi.org/10.1002/art.20841

[16] Calin, A., Edmunds, L., Kennedy. L.G. (1993) Fatigue in Ankylosing Spondylitis: Why Is It Ignored? The Journal of Rheumatology, 20, 991-995.

[17] Jones, S.D., Koh, W.H., Steiner, A., et al. (1996) Fatigue in Ankylosing Spondylitis: Its Prevalence and Relationship to Disease Activity, Sleep, and Other Factors. The Journal of Rheumatology, 23, 487-490.

[18] Roussou, E. and Sultana, S. (2010) The Bath Ankylosing Spondylitis Activity and Function Indices (BASDAI and BASFI) and Their Correlation with Main Symptoms Experienced by Patients with Spondyloarthritis. Clinical Rheumatology, 29, 869-874. http://dx.doi.org/10.1007/s10067-010-1411-9

[19] Turan, Y., Duruöz, M.T., Bal, S., et al. (2007) Assessment of Fatigue in Patients with Ankylosing Spondylitis. Rheumatology International, 27, 847-852. http://dx.doi.org/10.1007/s00296-007-0313-X

[20] Dernis-Labous, E., Messow, M. and Dougados, M. (2003) Assessment of Fatigue in the Management of Patients with Ankylosing Spondylitis. Rheumatology (Oxford), 42, 1523-1528. http://dx.doi.org/10.1093/rheumatology/keg421

[21] Wolfe, F., Michaud, K. and Pincus T. (2004) Fatigue, Rheumatoid Arthritis, and Anti-Tumor Necrosis Factor Therapy: An Investigation in 24831 Patients. The Journal of Rheumatology, 31, 2115-2120.

[22] Dagfinrud, H., Vollestad, N.K., Loge, J.H., et al. (2005) Fatigue in Patients with Ankylosing Spondylitis: A Comparison with the General Population and Associations with Clinical and seLf-Reported Measures. Arthritis Care \& Research, 53, 5-11. Http://Dx.Doi.Org/10.1002/Art.20910

[23] Yacoub, Y., Amine, B., Laatiris, A., et al. (2010) Assessment of Fatigue in Moroccan Patients with Ankylosing Spondylitis. Clinical Rheumatology, 29, 1295-1299. http://dx.doi.org/10.1007/s10067-010-1558-4

[24] Burgos-Vargas, R. and Casasola-Vargas, J.C. (2010) From Retrospective Analysis of Patients with Undifferentiated Spondyloarthritis (SpA) to Analysis of Prospective Cohorts and Detection of Axial and Peripheral SpA. The Journal of Rheumatology, 37, 1091-1095. http://dx.doi.org/10.3899/jrheum.100413 
Scientific Research Publishing (SCIRP) is one of the largest Open Access journal publishers. It is currently publishing more than 200 open access, online, peer-reviewed journals covering a wide range of academic disciplines. SCIRP serves the worldwide academic communities and contributes to the progress and application of science with its publication.

Other selected journals from SCIRP are listed as below. Submit your manuscript to us via either submit@scirp.org or Online Submission Portal.
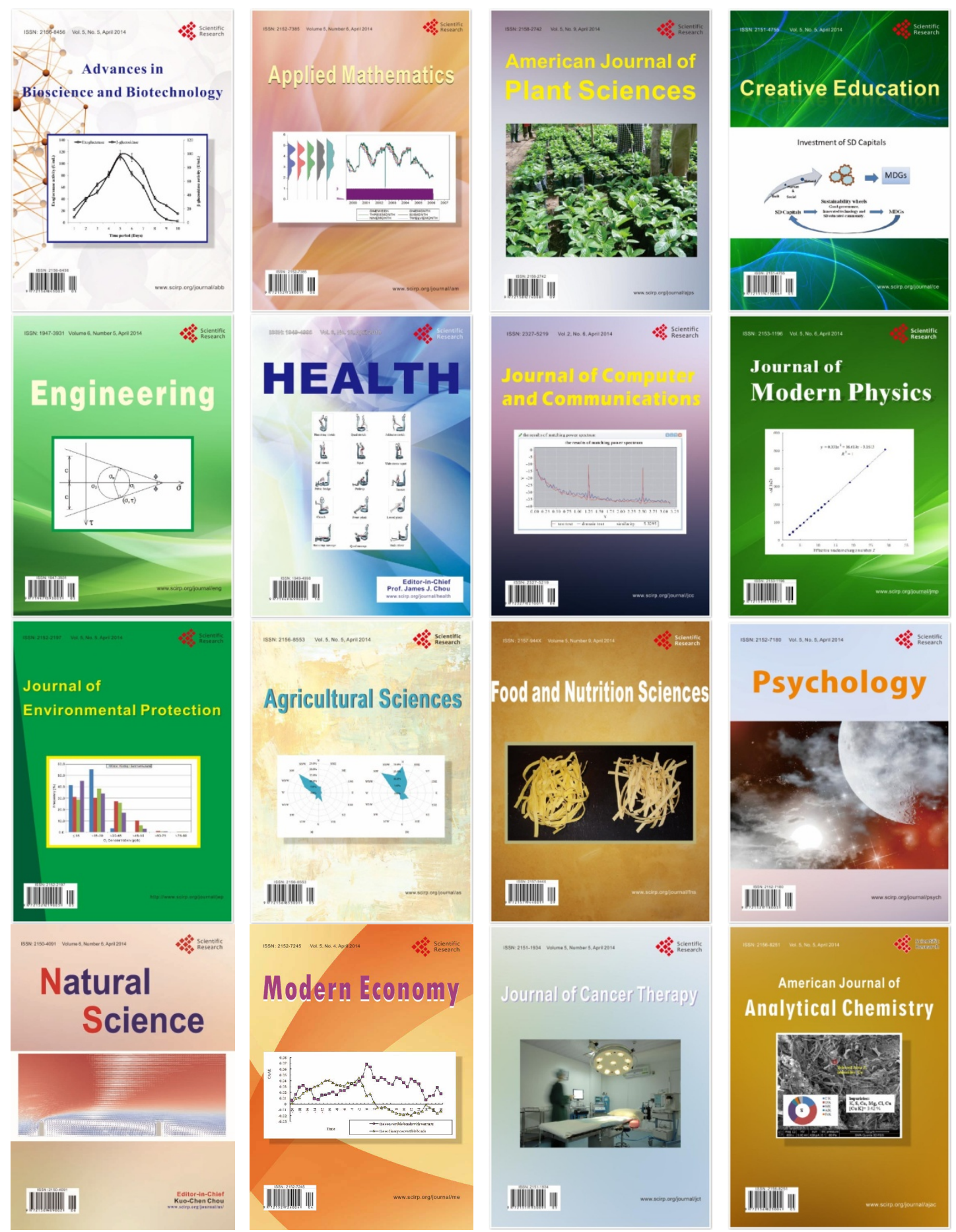